\title{
Oropharyngeal (p16-Negative) Cancer cN2 TNM Finding v8
}

National Cancer Institute

\section{Source}

National Cancer Institute. Oropharyngeal (p16-Negative) Cancer cN2 TNM Finding v8. NCI Thesaurus. Code C132945.

Oropharyngeal (p16-negative) cancer with metastasis in a single ipsilateral lymph node larger than $3 \mathrm{~cm}$ but not larger than $6 \mathrm{~cm}$ in greatest dimension and ENE(-); or metastases in multiple ipsilateral lymph nodes, none larger than $6 \mathrm{~cm}$ in greatest dimension and $\operatorname{ENE}(-)$; or metastases in bilateral or contralateral lymph nodes, none larger than $6 \mathrm{~cm}$ in greatest dimension and ENE(-). (from AJCC 8th Ed.) 